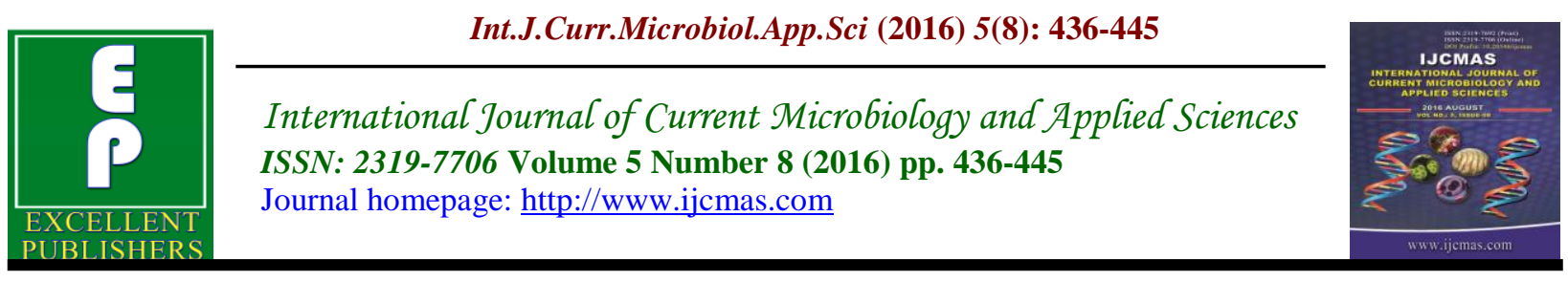

Original Research Article

http://dx.doi.org/10.20546/ijcmas.2016.508.047

\title{
Isolation and Characterization of Plant Growth Promoting Bacteria containing ACC Deaminase from Soil Collected from Central Himalayan Region of Uttarakhand, India
}

\author{
Dinesh Chandra* and A.K. Sharma \\ Department of Biological Sciences, CBS\&H, G.B. Pant University of Agriculture and \\ Technology, Pantnagar-263 145, U.S. Nagar, Uttarakhand, India \\ *Corresponding author
}

Keywords

ACC deaminase, PGPB,

stress,

PEG 8000.

Cyclopropane.

\section{Article Info}

Accepted:

21 July 2016

Available Online:

10 August 2016

\section{A B S T R A C T}

Bacteria possessing aminocyclopropane-1-carboxylate (ACC) deaminase activity reduce the level of stress induced ethylene production in plants conferring resistance and stimulating plants growth under various stressful conditions. A limited number of plant growth promoting bacteria (PGPB) possess the enzyme ACC deaminase (EC 4.1.99.4), a pyridoxal 5'-phosphate (PLP) dependent enzyme that catalyzes the cyclopropane ring fragmentation and deamination of $\mathrm{ACC}$, the immediate precursor of ethylene in all higher plants into $\alpha$-ketobutyrate and ammonia thereby lowering the level of plant ethylene. In this study, a total 297 bacteria were isolated from the 32 soil samples collected from the rainfed areas of Central Himalayan region of Kumaun, Uttarakhand, India. These soil bacteria were further screened for their ability to use ACC as a sole source of nitrogen in the DF salts minimal medium. In qualitative assay, 72 bacteria were found to be positive for ACC deaminase activity. Twenty eight bacterial isolates possessing the activity to cleave ACC were selected among the 72 isolates grown on the medium containing ACC as a sole nitrogen source were quantified and further characterized for different plant growth promoting traits Finally, 8 efficient bacterial isolates were selected on the basis of quantification of ACC deaminase activity and screened for drought tolerance using polyethylene glycol (PEG 8000). These selected bacteria withstand a substrate metric potential of $-1.0 \mathrm{MPa}(30 \% \mathrm{PEG}$ 8000) and therefore are considered to be drought-tolerant and could be helpful in eliminating the inhibitory effects caused by drought stress on the growth of plants.

\section{Introduction}

Soil bacteria that exert beneficial effects on plant health are referred to as plant growth promoting bacteria (PGPB). Currently, the use of PGPB as biofertilizers in sustainable farming practices has received greater attention in various parts of the world. PGPB stimulate plant growth through one or more mechanisms, either directly by supplying plant to phytohormones, phosphate solubilization nitrogen fixation and siderophores production or indirectly by protecting plant from phytopathogens through antagonistic mechanisms or generating induced systemic resistance 
(ISR) in host plants. In addition, certain PGPB can also protect plants from abiotic stressors through induced systemic tolerance (IST), which enables plants to tolerate the deleterious effects of abiotic stressors (Yang et al., 2009; Singh et al., 2015). One of the most common mechanisms of IST is accomplished through the production of ACC deaminase by the plant-associated bacteria. A number of PGPB belonging to various taxonomic groups such as Pseudomonas, Bacillus, Arthrobacter, Azospirillum, Burkholderia contain the enzyme ACC deaminase (EC 4.1.99.4) which hydrolyses ACC the immediate precursor of the plant hormone ethylene in all higher plants into $\alpha$-ketobutyrate and ammonium for use as carbon and nitrogen sources (Glick et al., 1995; Belimov et al., 2005). The ability of ACC utilizing PGPB to ameliorate plant growth inhibition caused by ethylene through a decrease in ACC content, thereby lowering the level of plant ethylene consequently enhancing plant stress tolerance (Penrose et al., 2001; Mayak et al., 2004). Treatment of plants with ACC deaminase producing bacteria results in the stimulation of root elongation and biomass production has been repeatedly documented, particularly when the plants were subjected to various stressful growth conditions (Glick et al., 1997; Van Loon and Glick, 2004).

Ethylene is a gaseous hormone, governs several developmental processes such as fruit ripening, abscission, germination, root architecture, flowering, leaf senescence and wilting (Abeles et al., 1992). Ethylene at low level stimulates several benefits to the plants however, excessive amounts of it results in the inhibition of root growth, abnormal development hypocotyl elongations, defoliation and growth retardation. The biosynthesis of ethylene is generally increased during both abiotic and biotic stresses including heavy metals
(Zhang et al., 2011), excess water (Grichko and Glick, 2001), high salt (Siddikee et al., 2011) and phytopathogens (Wang et al., 2000) and this result in a reduced rate of root and shoot growth. Therefore, the present study is aimed to isolate the efficient drought tolerant ACC deaminase producing bacteria from the soil of rainfed agriculture field which may improve growth of plant under drought stress conditions particularly.

\section{Materials and Methods}

\section{Soils sampling}

A total 32 soil samples were collected for the isolation of bacteria from Central Himalaya of Kumaun region Uttarakhand, India including four different sites of Bageshwar, and five different sites each of Almora and Pithoragarh. The sampling area comprised different altitudes of 14 villages (Table 1). The purpose of sampling was to isolate and screened the efficient drought tolerant ACC deaminase producing bacteria which may improve the growth of plants under various stressful conditions particularly drought.

\section{Isolation of bacteria by serial dilution and spread plating method}

For the isolation of bacteria $2.0 \mathrm{~g}$ of soil sample was weighed and mixed to $20 \mathrm{ml}$ phosphate buffer solution ( $\mathrm{pH} 7.0$ ) in 100 $\mathrm{ml}$ conical flask and kept on shaker at 120 $\mathrm{rpm}$ for $1 \mathrm{~h}$ and then dilution were made. Hundred microliter of aliquot from $10^{-4}$, $10^{-5}$ and $10^{-6}$ plated on different functional media such as Chrome-azurol $\mathrm{S}$ (CAS) medium, Pikovskya agar and nitrogen free Jenson agar medium incubated at $28{ }^{\circ} \mathrm{C}$ for 2-3 days. Plates were examined periodically for the appearance of bacterial colonies in respective medium. The discrete positive and morphologically different colonies were 
picked up and streaked on fresh agar plates for further purification. This procedure was repeated thrice to obtain pure bacterial culture and kept at $4{ }^{\circ} \mathrm{C}$ for further morphological and functional characterization.

\section{Screening of bacterial isolates for $\mathrm{ACC}$ deaminase activity}

Screening of bacterial isolates was done based on their ability to use ACC as a sole source of nitrogen in the minimal medium (Penrose and Glick, 2003). All the bacterial isolates were grown in $5 \mathrm{ml}$ of tryptic soy broth (TSB) medium for $24 \mathrm{~h}$ at $200 \mathrm{rpm}$ at $28^{\circ} \mathrm{C}$. The accumulated biomass was harvested by centrifugation at $8000 \mathrm{~g}$ for 10 min at $4^{\circ} \mathrm{C}$, then washed with sterile $0.1 \mathrm{M}$ Tris- $\mathrm{HCl}(\mathrm{pH} 7.5)$ and resuspended in $1 \mathrm{ml}$ of $0.1 \mathrm{M}$ Tris- $\mathrm{HCl}(\mathrm{pH}$ 7.5) and spot inoculated on Petri plates containing Dworkin and Foster (DF) salts minimal medium supplemented with $3.0 \mathrm{mM}$ ACC (Dworkin and Foster, 1958). Plates containing DF minimal medium without ACC served as negative control and with $(\mathrm{NH} 4)_{2} \mathrm{SO}_{4}$ as a nitrogen source served as positive control. The plates were incubated for 3 days at $28^{\circ} \mathrm{C}$. Growth of isolates on ACC supplemented plates was compared to positive and negative control plates. The isolates growing well on ACC supplemented plates were selected and further characterized for plant growth promoting traits.

\section{Quantification of ACC deaminase activity}

The capacity of selected bacteria to produce ACC deaminase was measured according to the method of Penrose and Glick (2003) using a standard curve of $\alpha$-ketobutyrate between 0.1 and $1.0 \mu \mathrm{M}$. Bacterial isolates were first cultured in tryptic soy broth (TSB) and grown up to late log phase in shaking incubator at $200 \mathrm{rpm}$ at $28^{\circ} \mathrm{C}$. The accumulated biomass was harvested by centrifugation at $8000 \mathrm{~g}$ for $10 \mathrm{~min}$ at $4{ }^{\circ} \mathrm{C}$. Bacterial pellets were then washed with $\mathrm{DF}$ salt minimal medium and also suspend the pellets into DF salt minimal medium containing ACC of final concentration 3.0 $\mathrm{mM}$. The bacterial cells were returned to shaking incubator for induction of ACC deaminase activity at $200 \mathrm{rpm}$ for $24 \mathrm{~h}$ at $28^{\circ} \mathrm{C}$. Then cells were harvested by centrifugation, washed with $0.1 \mathrm{M}$ Tris $\mathrm{HCl}$ ( $\mathrm{pH}$ 7.6). The collected bacterial cells were resuspended in $0.1 \mathrm{M}$ Tris $\mathrm{HCl}(\mathrm{pH} 8.5)$. Thirty microlitre of toluene was added to cell suspension and vortexed at highest setting for $30 \mathrm{~s}$. At this point $100 \mu \mathrm{l}$ of toluenized cells were set aside for protein assay at $4^{\circ} \mathrm{C}$. The remaining toluenized cell suspension was used immediately for ACC deaminase assay.

\section{ACC deaminase assay}

Twenty microliter of $0.5 \mathrm{M}$ ACC was added to $200 \mu \mathrm{l}$ toluenized cells, briefly vortexes and incubated at $30^{\circ} \mathrm{C}$ for $15 \mathrm{~min}$. Following this, $1 \mathrm{ml}$ of $0.56 \mathrm{M} \mathrm{HCl}$ was added, mixed by vortexing for $5 \mathrm{~min}$ at $8000 \mathrm{~g}$ at room temperature. The $1 \mathrm{ml}$ of resulting supernatant was mixed with $800 \mu \mathrm{l}$ of 0.56 $\mathrm{M} \mathrm{HCl}$. Then $300 \mu \mathrm{l}$ of 2,4dinitrophenylhydrazine was added to the above mixture in a glass test tube and incubated at $30^{\circ} \mathrm{C}$ for $30 \mathrm{~min}$. Following the addition and mixing of $2 \mathrm{ml}$ of $2 \mathrm{~N} \mathrm{NaOH}$, the absorbance was measured at $540 \mathrm{~nm}$ in a spectrophotometer (Ray-Leigh UV 2601).

\section{Protein estimation in toluenized bacterial cells}

Total soluble protein was measured by following the Lowry's method (Lowry et al., 1951). The protein concentration was estimated by referring to standard curve of bovine serum albumin (BSA). 
Characterization of PGPB for plant growth promoting (PGP) traits

\section{Indole acetic acid (IAA) production}

Production of IAA by bacteria was estimated according to the method of Gordon and Weber (1951). Tubes having 10 $\mathrm{ml}$ succinate broth with $100 \mu \mathrm{g} / \mathrm{ml}$ tryptophan were inoculated with actively growing bacterial cultures $\left(10^{8} \mathrm{cfu} / \mathrm{ml}\right)$ individually and incubated under shaking (120 rpm) conditions at $28{ }^{\circ} \mathrm{C}$ for $48 \mathrm{~h}$. After incubation, the cultures were centrifuged at 7,500 rpm for $10 \mathrm{~min}$ at room temperature. Then $2 \mathrm{ml}$ of Salkowski reagent was added to $1 \mathrm{ml}$ of culture supernatant and the resulting mixture was incubated at $30^{\circ} \mathrm{C}$ for $25 \mathrm{~min}$. Development of pink colour indicates IAA is produced by the test bacteria. Absorbance was recorded at $530 \mathrm{~nm}$ using UV/VIS spectrophotometer (Ray-Leigh UV 2601).The amount of IAA produced was calculated using the standard curve prepared (50-500 $\mu \mathrm{l})$ with known concentration of IAA.

\section{Phosphate solubilization on solid medium}

The bacterial isolates were subjected to phosphate solubilization according to the method of Pikovskaya (1948). Pikovskaya's medium containing insoluble tri-calcium phosphate (TCP) was poured into sterilized Petri plates and the isolate was spot inoculated and incubated at $28^{\circ} \mathrm{C}$ for $4-7$ days. The development of halo zone around the colony indicated the phosphate solubilizing capacity of test organisms.

\section{Siderophore production}

The bacterial isolates were spotted separately on Chrome-azurol S (CAS) medium and incubated at $28^{\circ} \mathrm{C}$ for 3-4 days. Formation of orange to yellow halo around the bacterial colonies confirmed the production of siderophores (Schwyn and Neilands, 1987).

\section{Production of ammonia}

The freshly grown culture of bacterial isolate was inoculated into $10 \mathrm{ml}$ peptone water in separate tubes and incubated for 48 $h$ at $28^{\circ} \mathrm{C}$. After the bacterial growth, Nessler's reagent $(0.5 \mathrm{ml})$ was added to each tube. Development of brown to yellow colour was observed as a positive test for ammonia production (Cappuccino and Sherman, 1992).

\section{Extracellular enzyme activities of PGPB}

\section{Catalase activity}

Catalase test was performed by taking a 3-4 drops of hydrogen peroxide $\left(3 \% \mathrm{H}_{2} \mathrm{O}_{2}\right)$ was added to $48 \mathrm{~h}$ old bacterial colony which is grown on nutrient agar medium. The release of gas bubbles indicated a positive test for catalase activity (Schaad, 1992).

\section{Protease activity}

The qualitative assay for protease production was performed on sterile skimmed milk agar plates. Isolates were spot inoculated and followed by incubation at $28^{\circ} \mathrm{C}$ and zone of clearance around the colony indicating the enzymatic degradation of protease (Jayasree et al., 2010).

\section{Amylase activity}

The bacterial isolates were spot inoculated on starch agar medium plates and incubated at $28^{\circ} \mathrm{C}$ for $48 \mathrm{~h}$. After incubation, plates were flooded with iodine solution. Yellow zones against a blue background around the colony indicated production of amylase (Collins, 1995). 


\section{Cellulase activity}

The bacterial isolates were spot inoculated on carboxymethylcellulose (CMC) agar plates and incubated at $28^{\circ} \mathrm{C}$ for $4-5$ days to allow for the secretion of cellulase. To visualize the hydrolysis zone, the incubated plates were flooded with an aqueous solution of $1 \%$ Congo red for $15 \mathrm{~min}$. After that the Congo red solution was poured off, and the plates were further flooded with $1 \mathrm{M}$ $\mathrm{NaCl}$ for $15 \mathrm{~min}$. Yellow-orange zone was observed which indicates the positive result for cellulase (Samira et al., 2011).

\section{Screening for drought tolerance of ACC deaminase producing PGPB}

Nutrient broth with different water potentials $(-0.5,-0.75,-1.0,-1.5 \mathrm{MPa})$ was prepared by adding appropriate concentrations of polyethylene glycol (PEG 8000) (Michel, (1983) and was inoculated with $1 \%$ of overnight raised bacterial cultures in nutrient broth. Three replicates of each isolate with each concentration were prepared. After incubation at $28^{\circ} \mathrm{C}$ under shaking conditions (120 rpm) for $24 \mathrm{~h}$, growth was estimated by measuring the optical density at $600 \mathrm{~nm}$ using a spectrophotometer (Ray-Leigh UV 2601). The growth of the isolates at various stress levels was recorded.

\section{Results and Discussion}

In present study, a total 297 bacteria were isolated on the basis of functional test on the three different medium such as CAS agar, Pikovaskya agar and Jenson agar. It has been found that 200 isolates were found to be positive for siderophore producers, 35 phosphate solubilizers and 62 nitrogen fixers. These soil bacteria were further screened for their ability to use ACC as a sole source of nitrogen in the DF salts minimal medium. In qualitative assay, 72 bacteria were found to be positive for ACC deaminase activity.

Utilization of ACC as a source of nitrogen by bacteria

The ability of bacterial isolates to utilize ACC as a source of nitrogen was determined on the basis of bacterial growth on DF salts minimal medium containing $3 \mathrm{mM}$ ACC. The bacterial isolates utilized ACC as nitrogen source but with different degrees of efficacy. These isolates were divided into three groups on the basis of their growth measured in terms of cell density at absorbance of $600 \mathrm{~nm}$ after $24 \mathrm{~h}$ of incubation. Bacterial isolates showing highest growth $(\mathrm{OD}>0.8)$ by utilizing ACC were categorized as Group-1. Similarly, isolates showing medium growth (OD $<0.8$ $0.5)$ were placed in Group- 2 while isolates exhibiting least growth (OD <0.5) were placed in Group-3 (Table 2). Shahzad et al. (2010) study also screened the ACC deaminase producing bacteria from the soil and exhibited different growth rates in DF salts minimal medium and categories into similar three groups highest, medium and least on the basis of absorbance taken at 600 nm.

Twenty eight bacterial isolates possessing the activity to cleave ACC were selected among the 72 isolates grown on the medium containing ACC as a sole $\mathrm{N}$ source were quantified and further characterized for different plant growth promoting traits (Table 3). From the Table 3 it has been observed that bacteria isolated from rain fed agriculture field of Central Himalaya of Uttarakhand exhibited different growth rates on DF salts medium containing ACC indicating that bacterial isolates possess different enzymatic potential to hydrolyze ACC. Also noticed that several bacterial isolates possesses multiple plant growth promoting traits and could be useful in the growth promotion of plant. 
Table.1 Source of soil samples collection

\begin{tabular}{|c|c|c|c|c|}
\hline $\begin{array}{l}\text { Soil } \\
\text { sampling } \\
\text { place }\end{array}$ & $\begin{array}{c}\text { Sites \& } \\
\text { Abbreviation }\end{array}$ & $\begin{array}{l}\text { Altitude } \\
\text { (Meter) }\end{array}$ & Location & Field condition \\
\hline \multirow{4}{*}{ Bageshwar } & Aary (RA) & 1831 & $\begin{array}{l}\mathrm{N} 29^{\circ} 52^{\prime} 12.0^{\prime \prime} \\
\mathrm{E} 79^{\circ} 26^{\prime} 35.9^{\prime \prime}\end{array}$ & $\begin{array}{l}\text { Irrigated, Organic (Cow Dung), Inorganic } \\
\text { (Urea And DAP) }\end{array}$ \\
\hline & Dwarson (DW) & 997 & $\begin{array}{l}\text { N } 29^{\circ} 52^{\prime} 18.1^{\prime \prime} \\
\text { E } 79^{\circ} 46^{\prime} 56.6^{\prime \prime}\end{array}$ & $\begin{array}{l}\text { Non-irrigated, Organic (Cow Dung), } \\
\text { Inorganic (NPK) }\end{array}$ \\
\hline & Bhatikot (BK) & 1014 & $\begin{array}{l}\mathrm{N} 29^{\circ} 52^{\prime} 23.5^{\prime \prime} \\
\mathrm{E} 79^{\circ} 47^{\prime} 44.6^{\prime \prime} \\
\end{array}$ & $\begin{array}{l}\text { Irrigated, Organic, Inorganic (DAP+ } \\
\text { Urea) }\end{array}$ \\
\hline & Mankot (MK) & 1499 & $\begin{array}{l}\mathrm{N} 29^{\circ} 49^{\prime} 44.5^{\prime \prime} \\
\mathrm{E} 79^{\circ} 49^{\prime} 16.9^{\prime \prime}\end{array}$ & Non-irrigated, Organic (Cow Dung) \\
\hline \multirow{5}{*}{ Pithoragarh } & Dharapani (DP) & 1876 & $\begin{array}{l}\mathrm{N} 29^{\circ} 36^{\prime} 18.8^{\prime \prime} \\
\mathrm{E} 080^{\circ} 11^{\prime} 43.0^{\prime \prime}\end{array}$ & Non-irrigated, Organic \\
\hline & Chandak (CD) & 1877 & $\begin{array}{l}\mathrm{N} 29^{\circ} 36^{\prime} 12.3^{\prime \prime} \\
\mathrm{E} 080^{\circ} 11^{\prime} 51.9^{\prime \prime}\end{array}$ & Non-irrigated, Organic, \\
\hline & $\begin{array}{l}\text { Mission Chandak } \\
(\mathrm{MC})\end{array}$ & 1895 & $\begin{array}{l}\mathrm{N} 29^{\circ} 36^{\prime} 18.3^{\prime \prime} \\
\mathrm{E} 080^{\circ} 11^{\prime} 65.6^{\prime \prime}\end{array}$ & Non-irrigated, Inorganic, Organic \\
\hline & Bhurmuni (BM) & 1883 & $\begin{array}{l}\mathrm{N} 29^{\circ} 39^{\prime} 23.9^{\prime \prime} \\
\mathrm{E} 080^{\circ} 13^{\prime} 56.3^{\prime \prime}\end{array}$ & Non-irrigated, Organic \\
\hline & Nakot (NK) & 1899 & $\begin{array}{l}\text { N } 29^{\circ} 46^{\prime} 18.4^{\prime \prime} \\
\mathrm{E} 080^{\circ} 13^{\prime} 44.7^{\prime \prime}\end{array}$ & Non-irrigated, Organic \\
\hline \multirow{5}{*}{ Almora } & Matella (MT) & 1194 & $\begin{array}{l}\mathrm{N} 29^{\circ} 37^{\prime} 42.3^{\prime \prime} \\
\mathrm{E} 79^{\circ} 37^{\prime} 48.1^{\prime \prime}\end{array}$ & Non-irrigated, Organic, Inorganic \\
\hline & Pasar (PS) & 1189 & $\begin{array}{l}\mathrm{N} 29^{\circ} 37^{\prime} 42.7^{\prime \prime} \\
\mathrm{E} 079^{\circ} 37^{\prime} 42.0^{\prime \prime}\end{array}$ & Non-irrigated, Organic, Inorganic \\
\hline & Chitai (CT) & 1205 & $\begin{array}{l}\mathrm{N} 29^{\circ} 37^{\prime} 11.2^{\prime \prime} \\
\mathrm{E} 079^{\circ} 42^{\prime} 06.5^{\prime \prime}\end{array}$ & Non-irrigated, Organic \\
\hline & Poonakot (PK) & 1608 & $\begin{array}{l}\mathrm{N} 29^{\circ} 37^{\prime} 18.2^{\prime \prime} \\
\mathrm{E} 079^{\circ} 38^{\prime} 26.7^{\prime \prime}\end{array}$ & Non-irrigated, Organic \\
\hline & Kasardevi (KD) & 1569 & $\begin{array}{l}\mathrm{N} 29^{\circ} 37^{\prime} 23.1^{\prime \prime} \\
\mathrm{E} 079^{\circ} 38^{\prime} 30.3^{\prime \prime}\end{array}$ & Non-irrigated, Organic \\
\hline
\end{tabular}

Table. 2 Growth of bacterial isolates on DF salt minimal medium supplemented with $3.0 \mathrm{mM} \mathrm{ACC}$

\begin{tabular}{|c|l|}
\hline Optical density (600 nm) & \multicolumn{1}{|c|}{ Bacterial isolates } \\
\hline \multirow{3}{*}{ Group 1 $(>0.8)$} & BKB24, BKB5, DPC29, MKB3, NKA2, NKA3, PKB2, \\
& PSA29, PSB4, MTA18 \\
\hline & DPA10, DPA9, DPC10, DPC13, DWB1, MTB1, MTB15, \\
MTB3, MTC15, MTC26, NKA1, PKA26, PKB14, PKB18, $2(<0.8-0.5)$ & $\begin{array}{l}\text { PKB2, PKB27, PKB3, PKB5, PKB6, PKB68, PSA12, PSA15, } \\
\text { PSA18, PSA19, PSA21, PSA9, PSB11, PSB9 }\end{array}$ \\
\hline & CDA3, CDA5, DPC14, DPC16, DPC29, DWB11, DWB13, \\
& DWB5, DWB7, DWC20, MKB13, MKB3, MTC22, MTC27, \\
Group 3 $(<0.5)$ & MTC30, NKA5, PKA25, PKB10, PKB17, PKB2, PKB3, \\
& PKB5, PKB7, PSA14, PSA22, PSA4, PSA5, PSA6, PSB12, \\
& PSB2, PSB6, PSB7, RAA1, RAA10 \\
\hline
\end{tabular}


Table. 3 The functional properties of selected bacterial isolates

\begin{tabular}{|l|l|l|c|c|c|c|}
\hline $\begin{array}{l}\text { Sr. } \\
\text { No. }\end{array}$ & $\begin{array}{c}\text { Bacterial } \\
\text { isolates }\end{array}$ & $\begin{array}{c}\text { ACC } \\
\text { deaminase }\end{array}$ & $\begin{array}{c}\text { ACC deaminase } \\
(\mu \mathrm{M} \alpha-\mathrm{KB} / \mathrm{mg} \\
\text { protein/mg dry wt. }\end{array}$ & $\begin{array}{c}\text { Phosphate } \\
\text { solubilizers }\end{array}$ & $\begin{array}{c}\text { Siderophore } \\
\text { producers }\end{array}$ & $\begin{array}{c}\text { Nitrogen } \\
\text { fixers }\end{array}$ \\
\hline 1 & BKB24 & + & $4.77 \pm 0.014$ & + & + & - \\
\hline 2 & BKB5 & + & $5.27 \pm 0.011$ & + & - & + \\
\hline 3 & DPC29 & + & $3.08 \pm 0.021$ & - & + & - \\
\hline 4 & MKB3 & + & $4.97 \pm 0.011$ & - & - & + \\
\hline 5 & NKA2 & + & $5.61 \pm 0.006$ & + & + & - \\
\hline 6 & NKA3 & + & $5.24 \pm 0.009$ & - & + & + \\
\hline 7 & PKB2 & + & $5.02 \pm 0.012$ & + & + & - \\
\hline 8 & PSA-29 & + & $4.65 \pm 0.028$ & - & + & - \\
\hline 9 & PKA25 & + & $1.09 \pm 0.006$ & + & + & + \\
\hline 10 & PSB6 & + & $1.07 \pm 0.006$ & - & + & - \\
\hline 11 & DPC10 & + & $1.15 \pm 0.011$ & - & - & + \\
\hline 12 & MTC15 & + & $0.43 \pm 0.052$ & - & + & - \\
\hline 13 & MTC22 & + & $1.42 \pm 0.004$ & - & + & - \\
\hline 14 & MTC26 & + & $5.63 \pm 0.050$ & - & - & - \\
\hline 15 & RAA1 & + & $0.38 \pm 0.003$ & - & + & + \\
\hline 16 & RAA5 & + & $0.34 \pm 0.007$ & + & + & - \\
\hline 17 & RAA6 & + & $0.87 \pm 0.004$ & - & + & - \\
\hline 18 & PKB5 & + & $0.83 \pm 0.004$ & - & + & - \\
\hline 19 & PKB6 & + & $0.87 \pm 0.024$ & + & + & - \\
\hline 20 & PKB10 & + & $0.41 \pm 0.001$ & - & + & - \\
\hline 21 & PKB14 & + & $0.61 \pm 0.023$ & - & + & - \\
\hline 22 & DPC13 & + & $0.88 \pm 0.006$ & - & - & + \\
\hline 23 & PKA26 & + & $0.14 \pm 0.003$ & + & + & - \\
\hline 24 & PSA14 & + & $0.94 \pm 0.004$ & - & - & - \\
\hline 25 & PSA21 & + & $0.60 \pm 0.011$ & - & - & - \\
\hline 26 & PKB3 & + & $1.81 \pm 0.040$ & + & + & - \\
\hline 27 & MTB15 & + & $3.66 \pm 0.017$ & - & + & + \\
\hline 28 & NKA1 & + & $4.89 \pm 0.008$ & - & - & - \\
\hline & + & + & + & + & + \\
\hline
\end{tabular}

The presence of an activity is indicated by "+" whereas the absence is indicated by "-". Values are the means of 3 replicates \pm S.E. 
Table.4 Plant growth promoting characteristics and hydrolytic enzymes of bacterial isolates.

\begin{tabular}{|l|c|c|c|c|c|c|}
\hline \multirow{2}{*}{$\begin{array}{l}\text { Bacterial } \\
\text { isolates }\end{array}$} & \multicolumn{6}{|c|}{ PGPB traits and extracellular hydrolytic enzymes } \\
\cline { 2 - 7 } & IAA & Ammonia & Cellulase & Amylase & Protease & Catalase \\
\hline BKB24 & + & + & - & + & - & + \\
\hline BKB5 & - & + & - & + & + & + \\
\hline DPC29 & + & + & + & - & - & + \\
\hline MKB3 & - & - & + & - & - & + \\
\hline NKA2 & + & - & - & + & + & - \\
\hline NKA3 & - & + & - & - & - & + \\
\hline PKB2 & + & - & + & - & + & - \\
\hline PSA-29 & - & + & + & + & - & - \\
\hline
\end{tabular}

For further study, 8 efficient bacterial isolates (BKB24, BKB5, DPC29, MKB3, NKA2, NKA3, PKB2 and PSA29) were selected on the basis of their ACC deaminase activity and further characterized for indole acetic acid (IAA), ammonia production and extracellular hydrolytic enzymes (Table 4).

\section{Growth of ACC deaminase producing bacterial isolates in tryptic soy broth supplemented with PEG 8000}

The selected eight ACC deaminase producing bacterial isolates showed maximum growth in the absence of PEG, while growth was significantly decreased with increasing concentrations of polyethylene glycol (PEG). However, all eight bacterial isolates were able to grow at a metric potential of -1.0 MPa (Fig.1). Study of Ali et al., (2013) also screened the ACC deaminase producing bacteria for drought tolerance using PEG indicated that introduction of drought tolerant bacteria containing ACC deaminase activity in the drought stressed soils can alleviate stress in the crop plants by lowering stress induced ethylene production.

Current agriculture practices suffering from the increased incidences of abiotic and biotic stresses. Under abiotic stresses, drought, salinity and temperature are the major constraint for plant growth and productivity and are likely to further increase in future due to climate change. Bacteria containing ACC deaminae activity could play a significantly role in these stress conditions, if we can exploit their unique attributes of tolerance to extremities, their ubiquity, genetic diversity, their interaction with crop plants and develop methods for their successful deployment in agriculture production. Thus, further studies are needed to examine the nature of these isolates containing ACC deaminase activity and to harness their potential as bio-inoculants under various stressful conditions particularly drought.

\section{References}

Abeles, F.B., Morgan, P.W., Saltveit Jr, M.E. 1992. Ethylene in plant biology. San Diego: Academic.

Ali, S.Z., Sandhya, V., Rao, L.V. 2013. Isolation and characterization of drought-tolerant ACC deaminase and exopolysaccharide-producing

fluorescent Pseudomonas sp. Ann. Microbiol., 1-10.

Belimov, A.A., Hontzeas, N., Safronova, V. I., Demchinskaya, S. V., Piluzza, G., 
Bullitta, S., Glick, B.R. 2005. Cadmium-tolerant plant growthpromoting bacteria associated with the roots of Indian mustard (Brassica juncea L. Czern.). Soil Biol. Biochem., 37: 241-250.

Cappuccino, J.C., Sherman, N. 1992. Microbiology: A Laboratory Manual, Wesley Pub. Co., New York.

Collins, C.H., Patricia M., Lyne, J.M. 1995. Grange, Collins and Liyne's Microbiological Methods, 7th Edn, Butterworth-Heinemann, UK. p.100.

Dworkin, M., Foster, J.W. 1958. Experiments with some microorganisms which utilize ethane and hydrogen. J. Bacterial., 75: 592603.

Glick, B.R., Karaturovíc, D.M., Newell, P.C. 1995. A novel procedure for rapid isolation of plant growth promoting pseudomonads. Can. J. Microbiol. 41: 533-536.

Glick, B.R., Liu, C., Ghosh, S., Dumbroff, E.B. 1997. Early development of canola seedlings in the presence of the plant growth-promoting rhizobacterium Pseudomonas putida GR12-2. Soil Biol. Biochem. 29: 12331239 .

Gordon, S.A., Weber, R.P. 1951. Colorimetric estimation of indoleacetic acid. Plant Physiol., 26: 192-195.

Grichko, V.P., Glick, B.R. 2001. Amelioration of flooding stress by ACC deaminase-containingplant growth-promoting bacteria. Plant Physiol. Biochem., 39: 11-17.

Jayasree, D., Kumari, T.D., Kishor, P.B., Lakshmi, M.V., Narasu, M.L. 2010. Optimization of production protocol of alkaline protease by Streptomyces pulvereceus. arXiv preprint arXiv: 1002.0048.

Lowry, O.H., Rosebrough, N.J., Farr, A.L.,
Randall, R.J. 1951. Protein measurement with the Folin phenol reagent. J. Biol. Chem., 193: 265-275.

Mayak, S., Tirosh, T., Glick, B.R. 2004. Plant growth-promoting bacteria that confer resistance to water stress in tomatoes and peppers. Plant Sci. 166: 525-530.

Michel, B.E. 1983. Evaluation of the water potentials of solutions of polyethylene glycol 8000 both in the absence and presence of other solutes. Plant Physiol., 72: 66-70.

Penrose, D.M., Glick, B.R. 2003. Methods for isolating and characterizing ACC deaminase-containing plant growth-promoting rhizobacteria. Physiol. Plant. 118: 1015.

Penrose, D.M., Moffatt, B.A., Glick, B.R. 2001. Determination of 1aminocycopropane-1-carboxylic acid (ACC) to assess the effects of ACC deaminase-containing bacteria on roots of canola seedlings. Can. J. Microbiol., 47: 77-80

Pikovskaya, R.I. 1948. Mobilization of phosphorus in soil in connection with vital activity of some microbial species. Mikrobiologiya, 17: e370.

Samira, M., Mohammad, R., Gholamreza, G. 2011. Carboxymethyl-cellulase and filter-paperase activity of new strains isolated from Persian Gulf. Microbiol. J., 1: 8-16.

Schaad, N.W. 1992. Laboratory Guide for Identification of Plant Pathogenic Bacteria, 2nd Edn,International Book Distributing Co, Lucknow. p. 44-58.

Schwyn, B., Neilands, J.B. 1987. Universal chemical assay for the detection and determination of siderophores. Anal. Biochem., 160: 47-56.

Shahzad, S.M., Khalid, A., Arshad M., Rehman, K. 2010. Screening rhizobacteria containing ACC- 
deaminase for growth promotion of chickpea seedlings under axenic conditions. Soil Environ., 29: 38-46.

Siddikee, M.A., Glick, B.R., Chauhan, P.S., jong Yim, W., Sa, T. 2011. Enhancement of growth and salt tolerance of red pepper seedlings (Capsicum annuum L.) by regulating stress ethylene synthesis with halotolerant bacteria containing 1aminocyclopropane-1-carboxylic acid deaminase activity. Plant Physiol. Biochem., 49: 427-434.

Singh, R.P., Jha, P., Jha, P.N., 2015a. The plant-growth-promoting bacterium Klebsiella sp. SBP-8 confers induced systemic tolerance in wheat (Triticum aestivum) under salt stress. J. Plant Physiol., 184: 57-67.

van Loon, L.C., Glick, B.R. 2004. Increased plant fitness by rhizobacteria. In Molecular ecotoxicology of plants (pp.
177-205). Springer Berlin Heidelberg. Wang, C., Knill, E., Glick, B.R., Defago, G. 2000. Effect of transferring 1aminocyclopropane-1-carboxylic acid (ACC) deaminase genes into Pseudomonas fluorescens strain CHA0 and its gac A derivative CHA96 on their growth-promoting and disease-suppressive capacities. Can. J. Microbiol., 46: 898-907.

Yang, J., Kloepper, J.W., Ryu, C.M. 2009. Rhizosphere bacteria help plants tolerate abiotic stress. Trends Plant Sci., 14: 1-4.

Zhang, Y.F., He, L.Y., Chen, Z.J., Wang, Q.Y., Qian, M., Sheng, X.F. 2011. Characterization of ACC deaminaseproducing endophytic bacteria isolated from copper-tolerant plants and their potential in promoting the growth and copper accumulation of Brassica napus. Chemosphere, 83: 57-62.

\section{How to cite this article:}

Dinesh Chandra and A.K. Sharma. 2016. Isolation and Characterization of Plant Growth Promoting Bacteria containing ACC Deaminase from Soil Collected from Central Himalayan Region of Uttarakhand, India. Int.J.Curr.Microbiol.App.Sci. 5(8): 436-445. doi: http://dx.doi.org/10.20546/ijcmas.2016.508.047 